\title{
Degradable Controlled Release Capsule Dosage Form
}

National Cancer Institute

\section{Source}

National Cancer Institute. Degradable Controlled Release Capsule Dosage Form. NCI

Thesaurus. Code C68949.

A capsule designed to dissolve after releasing the active and/or inert ingredient(s) at a controlled rate. 